\title{
Suggestions for Improving the Salary Design of an Electrical Appliance Company's Sales Staff
}

\author{
Haisheng Liu ${ }^{1, a^{*}}$ and Mingwei Ma,b \\ ${ }^{1}$ School of Business Administration, Changchun Sci-Tech University, Changchun,China, 130600 \\ ${ }^{2}$ Faculty of Continuing Education, Communication University of China, Beijing,China, 100024 \\ acalloftheduty1988@hotmail.com, b arbey33163@163.com \\ * The Corresponding Author
}

Keywords: Electrical appliance company; Sales staff; Salary design; Private enterprise

\begin{abstract}
The working enthusiasm of sales staff determines the performance of enterprises to a certain extent. A set of reasonable salary systems can maximize the working enthusiasm of the sales staff. Through optimizing the original salary system of the sales staff of an electrical appliance company, this paper puts forward the optimization salary mode of the sales staff which focuses on the basic salary, sales commissions, individual performance and team performance, so as to achieve effective incentives to sales staff to improve sales performance.
\end{abstract}

\section{Introduction}

As the market competition becomes more and more intense, how to mobilize the working enthusiasm and initiative of the staff to maximize the benefit of the enterprise becomes the primary problem of the enterprise [1,2]. Motivating measure is the main means to mobilize the working enthusiasm and initiative of employees. As an important means of incentive mechanism, salary incentive naturally becomes the focus of enterprises. The reasonable salary system can effectively stimulate the working enthusiasm of the sales staff, improve the profit and make the enterprise develop continuously and healthfully $[3,4]$.

\section{The Work Characteristics of the Sales Staff}

The salesman refers to the person who sells goods and serves customers. The salesman referred to in this paper is the salesman in the household electrical appliance industry. These salesmen are mainly responsible for finding distributors for the enterprises and developing new customers continuously, and maintaining the relationship with these distributors so as to cooperate with them for a long time [5]. The working characteristics of salesmen are that their work time and space are relatively independent. Their work performance is influenced by many factors, which is also the cause of the unstable performance of the sales staff. The sales link is very important for the electrical appliance enterprises, which directly determines the profits of the enterprises, and it is the basis for the survival and development of the enterprises [6,7].

\section{Analysis of the Salary System of the Sales Staff of an Electrical Appliance Company}

The salary standards for the current sales staff of the enterprise are as follows: The salary is divided into five levels, which is composed of three parts: the basic salary, variable pay(sales commissions, performance bonus and travelling allowance) and welfare. The basic salary of the sales staff is 900 $\mathrm{CNY}$, and the level difference is $300 \mathrm{CNY}$. The monthly sales volume is $30000 \mathrm{CNY}$. If the salesman completes the sales task for three months, his salary will be raised by one level, otherwise, his salary will be decreased by one level. The variable pay includes the sales commissions, performance bonus, and travelling allowance. The higher the proportion of sales, the higher the sales commissions. Performance bonuses are linked to the excess sales, which are divided into six levels ranging from 100 
CNY to $1000 \mathrm{CNY}$. Welfare includes pension insurance, unemployment insurance, medical insurance, employment injury insurance and housing fund [8].

Through the analysis of the salary system above, it is found that the current salary system of this company has the following problems: Firstly, the company uses the same salary system as the old employee for the new employees. Due to the low salary, new employees lack enthusiasm. In addition, the new market is difficult to exploit, and it is easy to discourage new employees. Secondly, the enterprise only provides basic insurance, and the welfare and allowances are less, so that the employees' satisfaction to the enterprise is not high and the brain drain is easily caused. Thirdly, the incentive salary only includes performance bonus and sales commissions. For the middle and senior sales personnel who have completed the total sales of $70 \%$ of the enterprise, the enterprise has not given the emphasis on the salary distribution, and the incentive is insufficient for the outstanding sales staff. Finally, the excessive emphasis on individual performance leads some salesmen to focus on their own performance and neglect the role of the team, which will damage to the interests of the enterprise $[9,10]$.

\section{The Optimization of the Salary System of the Sales Staff of an Electrical Appliance Company}

In view of the problems, this paper puts forward the following suggestions for the salary system of the sales staff of an electrical appliance company.

Establishing Special Salary. The special salary system for senior sales staff should be established, such as year-end bonus, employee stock ownership plan, etc. For such employees, the form of annual salary system should be adopted. The enterprise should optimize the salary system of the new employees, and provide some protective measures for new salesmen. In the period of protection, new employees can enjoy a higher basic salary, so as to increase the sense of belonging and gumption of the new employees.

Combining Team Performance and Personal Performance. The enterprise should introduce team performance to complement the original individual performance. On the basis of the personal performance bonus, the enterprise should set up team sales tasks and performance rewards to improve employees' team awareness and cooperation spirit.

Optimizing the Salary Structure. The optimized salary structure is shown in Fig.1. Among them, the basic salary of sales staff at all levels is increased by $100 \mathrm{CNY}$, the basic salary of the probationary sales staff is increased to $800 \mathrm{CNY}$, and some protective measures are given. The improved basic salary of the sales staff at all levels is shown in Table 1.

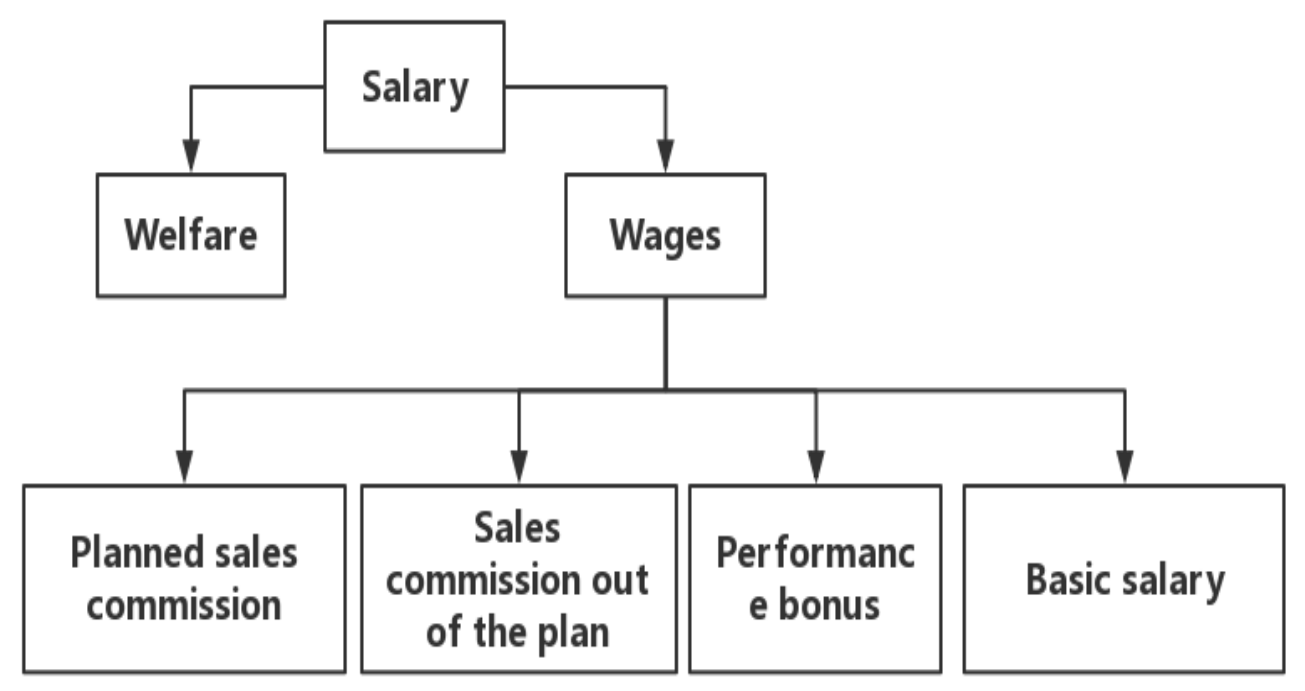

Figure 1. Finite The improved salary system 
Table 1 The comparison table of the basic salary of sales staff at all levels(1000 CNY)

\begin{tabular}{cccc}
\hline Level & Basic salary & $\begin{array}{c}\text { Monthly sales } \\
\text { volume }\end{array}$ & Annual sales task \\
\hline $\begin{array}{c}\text { Fifth-level salesmen } \\
\text { Fourth-level } \\
\text { salesmen }\end{array}$ & 1 & 30 & 300 \\
$\begin{array}{c}\text { Third-level } \\
\text { salesmen }\end{array}$ & 1.3 & 40 & 400 \\
$\begin{array}{c}\text { Second-level } \\
\text { salesmen }\end{array}$ & 1.5 & 50 & 500 \\
First-level salesmen & 2 & 60 & 600 \\
\hline
\end{tabular}

The sales commission is divided into two parts: the planned sales commission and the sales commission out of plan, as shown in Table 2. The performance bonus is divided into personal performance bonus and team performance bonus. The incentive effect is enhanced by enriching the content of the bonus, and the performance bonus of the team overfulfilling the task is shown in Fig. 3 . Increasing the performance bonus for excess task can increase the team collaboration and further improve sales performance.

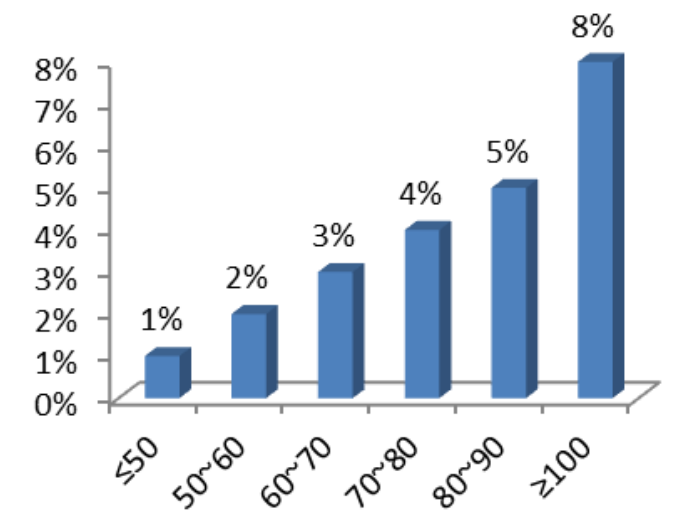

Figure 2. Finite Commission percentage of sales staff

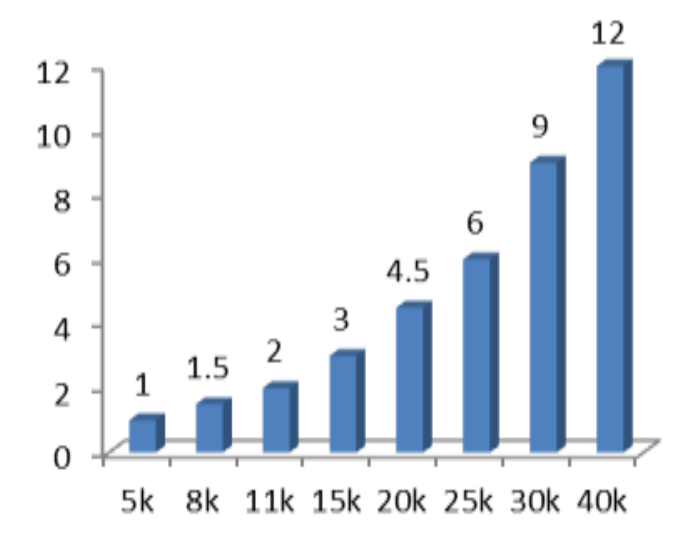

Figure 3. Finite Performance bonuses for overfulfilling the task by the team

On the basis of the original basic insurance, the paid vacation, employee travelling subsidies and some free training programs are added. 
Table 2 The welfare program table of sales staff at all levels (CNY)

\begin{tabular}{cccc}
\hline Level & Paid vacation time & $\begin{array}{c}\text { Travel expense } \\
\text { subsidy }\end{array}$ & Free training fee \\
\hline $\begin{array}{c}\text { Fifth-level salesmen } \\
\text { Fourth-level } \\
\text { salesmen }\end{array}$ & 3 & 500 & 300 \\
$\begin{array}{c}\text { Third-level } \\
\text { salesmen }\end{array}$ & 4 & 700 & 450 \\
$\begin{array}{c}\text { Second-level } \\
\text { salesmen }\end{array}$ & 5 & 900 & 600 \\
First-level salesmen & 6 & 1200 & 750 \\
\hline
\end{tabular}

After adopting a new salary system, the sales performance of an electrical appliance company that year increased by $5.5 \%$ on year-on-year basis, the sales staff's satisfaction to the company increased by $13 \%$ on year-on-year basis, and the turnover rate of employees decreased by $7 \%$ on year-on-year basis. It can be seen that the new salary system effectively mobilizes the enthusiasm of the sales staff and improves the performance of the enterprises.

\section{Summary}

The salary system of the sales staff is closely related to the working enthusiasm of the sales staff and the sales performance of the enterprises. Aiming at the problems existing in the salary design of the sales staff of an electrical appliance company, this paper puts forward the salary optimization system for the sales staff. A new set of salary systems are designed by combining team performance bonus and personal performance bonus, redesigning the salary system and improving the salary structure. Through adopting a new salary system, the sales performance of the enterprise that year increased by $5.5 \%$ on year-on-year basis, and the employee satisfaction was also improved.

\section{Acknowledgements}

The work reported in this paper is supported by the project of Educational Science Planning in Jilin (CZI2019).

\section{References}

[1] Armstrong M, Page K. A Handbook of Human Resource Management Practice ,7th ed.,[M]. Kogan Page Ltd, London ,2014.

[2] Heijdra B. Foundations of Modern Macroeconomics[M]. Oxford University Press, London ,2009:399-401.

[3] Krumina I, Krumins G, Rozentale S. Vidzeme Region of Latvia: Knowledge Management in Micro Enterprises [J]. Procedia - Social and Behavioral Sciences, 2015, 213:781-786.

[4] Johnson S, Kochhar K, Mitton T, et al. Malaysian Capital Controls: Macroeconomics and Institutions[J]. Nber Chapters, 2017, 06(51):529-574.

[5] Alalwan J A, Thomas M A, Weistroffer H R. Decision support capabilities of enterprise content management systems: An empirical investigation[J]. Decision Support Systems, 2014, 68:39-48.

[6] Hullavarad S, O'Hare R, Roy A K. Enterprise Content Management solutions-Roadmap strategy and implementation challenges[J]. International Journal of Information Management, 2015, 35(2):260-265.

[7] Kulcu O, Cakmak T. Convergence of the Records Management and Enterprise Content Management in the Digital Environment[J]. Procedia - Social and Behavioral Sciences, 2012, 62(1):194-197.

[8] House C J C. Integrating Barriers to Caucasian Lesbians' Career Development and Super's 
Life - Span, Life - Space Approach[J]. Career Development Quarterly, 2004, 52(3):246-255.

[9] Hansen, Jo-Ida C.Leuty, Melanie E. Work Values across Generations.[J]. Journal of Career Assessment, 2012, 20(1):34-52.

[10] Nkomo E. Motivation, work values, organisational commitment and job satisfaction : age and generational cohort effects.[J]. American Journal of Physiology, 2014, 277(4):E668. 